\title{
Perianal Tuberculosis in A Male Patient with Diabetes Mellitus
}

\author{
Diyabetli Erkek Bir Hastada Perianal Tüberküloz
}

Murat Özgür Kılıç*1, Cemile Sağlam², Cevat Can $^{3}$

\section{ÖZET}

Perianal tüberküloz (TB) tüberküler enfeksiyonun nadir bir formudur ve akut apse, kronik ülser, nodüler lezyon ve fistül gibi değişken klinik şekilleri vardır. Ülseratif, verrüköz, lupoid ve miliyer formlarda prezente olmasına karşın, yüzeysel ülser en sık bildirilen morfolojik tiptir. Crohn hastalığı, herpetik ülser, malignite ve diğer granülomatöz hastalıklar perianal tüberkülozun ayırıcı tanısında düşünülmelidir. Tanı esas olarak histolojik ve/veya bakteriyolojik incelemelere dayanır. Altı aylık anti-tüberküloz tedavisi standart tedavidir, ve cerrahi sadece fistül ve apsede endikedir. Burada, diabetes mellituslu bir erkek hastada nadir bir perianal tüberküloz olgusu sunuldu.

Anahtar kelimeler: Diyabet, erkek, perianal tüberküloz, tanı, tedavi

\begin{abstract}
Perianal tuberculosis is a rare form of tubercular infection, and has variable clinical pictures such as acute abscess, chronic ulcer, nodulary lesion, and fistula. Although it can be presented in ulcerative, verruous, lupoid and miliary forms, superficial ulceration is the most commonly reported morphological type. Crohn's disease, herpetic ulcer, malignancy, and other granulomatous diseases should be considered in the differential diagnosis of perianal tuberculosis. The diagnosis mainly depends on histologic and/or bacteriologic examination. Six-month anti-tuberculous therapy is the standard treatment, and surgery is only indicated for fistula and abscess. Herein, a rare case of perianal tuberculosis in a male patient with diabetes mellitus was presented.
\end{abstract}

Key words: Diabetes, diagnosis, male, perianal tuberculosis, treatment

Received / Geliş tarihi: 09.12.2016, Accepted / Kabul tarihi: 14.01.2017

${ }^{1}$ Department of General Surgery, Ankara Numune Training and Research Hospital

${ }^{2}$ Ankara Yenimahalle Tuberculous Control Dispensary

${ }^{3}$ Depatment of Pathology, Faculty of Medicine, Konya Karatay University

*Address for Correspondence / Yazışma Adresi: Department of General Surgery, Numune Training and Research Hospital, Ankara, Turkey

E-mail: murat05ozgur@hotmail.com

Kılıç MÖ, Sağlam C, Can C. Perianal Tuberculosis in A Male Patient with Diabetes Mellitus, TJFMPC, 2017;11(1): 64-66.

DOI: $10.21763 / \mathrm{tjfmpc.295954}$ 


\section{INTRODUCTION}

Gastrointestinal TB constitutes about less than $1 \%$ of all TB cases. ${ }^{1}$ Perianal involvement is an extremely rare form, and has variable clinical pictures such as acute abscess, chronic ulcer, nodule, and fistula. The diagnosis can be easily confused with several benign and malignant diseases such as Crohn's disease, herpetic ulcer, and anal squamous cancer. In this paper, a rare case of perianal $\mathrm{TB}$ in a male patient with diabetes mellitus was presented.

\section{CASE}

A 60-year-old man presented with long-standing perianal nodular lesions. He had undergone open drainage for perianal abscess three months ago, and had received multiple antibiotherapies. In physical examination, chronic nodular lesions with indurated area were found on the perianal region (Figure 1). Digital rectal examination was normal, and no abnormality was found on colonoscopy. Since the colonoscopy was normal, and the lesion was longstanding and resistant to therapy, a punch biopsy was taken for a pre-diagnosis of tuberculosis or an atypical infection. Histopathology showed epithelioid granulomas and Langhans' multinucleated giant cells, with caseous necrosis (Figure 2). Tuberculous (TB) skin test was positive; however, chest X-ray revealed no abnormality. The patient was treated with isoniazid $(5 \mathrm{mg} / \mathrm{kg}$ day) and rifampicin $(10 \mathrm{mg} / \mathrm{kg}$ day) for 6 months. In the first 2-month period, pyrazinamide $(30 \mathrm{mg} / \mathrm{kg}$ day) and streptomycin (15 $\mathrm{mg} / \mathrm{kg}$ day) were administered. After the treatment, the lesion has disappeared. No recurrence was observed during 18-months follow-up.

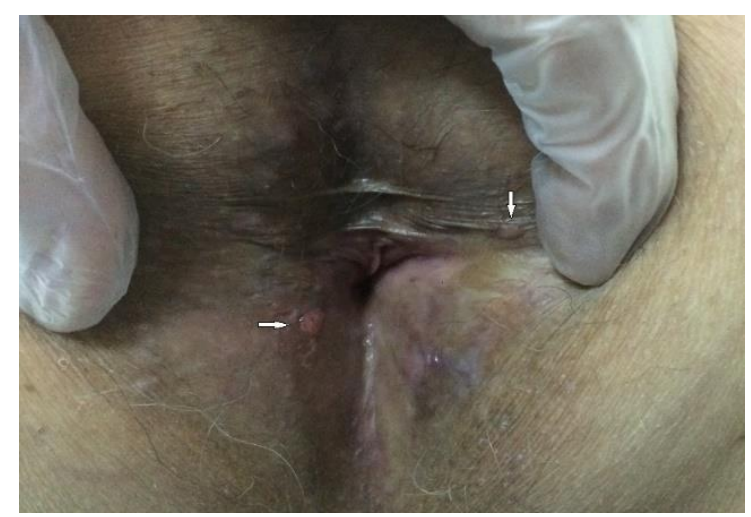

Figure 1. The view of perianal verrucous lesions (arrows) and indurated area.

\section{DISCUSSION}

Although perianal TB can be presented in ulcerative, verrucous, nodular, lupoid and miliary

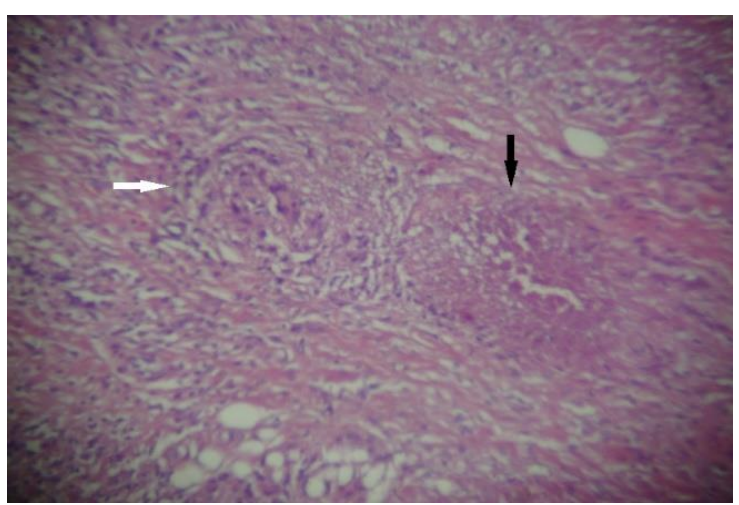

Figure 2. Histopathological appearance of granulomas containing Langhans giant cells (white arrow) and caseous necrosis (black arrow) ( $\mathrm{HE} \times$ 10).

forms, superficial ulceration is the most common reported morphological type 2, patients rarely present with acute perianal abscess as in our case. Various underlying diseases related to immunocompromised conditions including diabetes, cancer, and human immunodeficiency virus positivity, can be found in these patients. ${ }^{3}$ Similarly, our patient had diabetes mellitus for a long time. Active pulmonary TB can be also accompanied with perianal TB, therefore such patients should be evaluated by chest radiography. ${ }^{3}$ Our patient had no active, past or contact history of TB. Crohn's disease, herpetic ulcer, and malignancy should be considered in the differential diagnosis of chronic perianal ulceration. Therefore, colonoscopy and biopsy from the lesions should be a part of the diagnostic work-up. The diagnosis mainly depends on histologic and/or bacteriologic examination. The presence of epithelioid and giant cells with caseous necrosis is the typical histopathologic finding. Culture is gold standard diagnostic method; however, requires a lot of time that may lead delay in the treatment. Polymerase chain reaction is a rapid test with high sensitivity and specificity but high cost limits its general use. ${ }^{2}$ Standard anti-TB therapy for six months is the mainstay treatment with high success, and surgery is only indicated for fistula and abscess. ${ }^{4}$

In conclusion, perianal TB should be considered in the differential diagnosis of long standing anal lesions, particularly in patients from endemic areas of TB. Medical therapy should be the mainstay treatment modality, and surgery should be only considered in cases of fistula and abscess. 


\section{REFERENCES}

1. Yurt S, Kosar F, Isik N, Urer HN. Two cases of pulmonary tuberculosis with extrapulmonary involvement in tongue and anus. Respiratory Medicine Extra 2005;1:1-3.

2. Matthew S. Anal tuberculosis: report of a case and review of literature. Int J Surg 2008;6:e36-9.
3. Tago S, Hirai Y, Ainoda Y, Fujita T, Takamori M, Kikuchi K. Perianal tuberculosis: A case report and review of the literature. World $\mathrm{J}$ Clin Cases 2015;3:848-52.

4. Ibn Majdoub Hassani K, Ait Laalim S, Toughrai I, Mazaz K. Perianal tuberculosis: a case report and a review of the literature. Case Rep Infect Dis 2012;2012:852763. 